\section{Investigation of Decision-Making Skills of Fourth Grade Students According to Student and Teacher Opinions}

\begin{tabular}{ll}
\hline Received: & 27 August 2019 \\
Revised: & 10 October 2019 \\
Accepted: & 19 November 2019 \\
ISSN: 1307-9298 \\
Copyright ( IEJEE \\
www.iejee.com
\end{tabular}

DOI: $10.26822 /$ iejee. 2019257664

\begin{abstract}
Studies focus on the importance of developing decision-making skills, which are among thinking skills, at early ages and highlight that these skills, if not developed at early ages, lead to some problems at the later stages of individuals' lives. Curricula on the level of primary school in Turkey, based on their visions, aim to train individuals with decision-making skills. In reaching this objective, it is important to determine what type of problems are experienced in the process, to what extent objectives can be reached and what the factors that affect the process are. With this mixed method study, it was aimed to examine the problems experienced in and the existing situation of development of decision-making skills. The design of the study was adopted as the convergent parallel design. The participants of the study consisted of 9 teachers who served as $4^{\text {th }}$ grade teachers and $5434^{\text {th }}$ grade students from different socioeconomic levels. As the data collection instruments, the study utilized a "Student Personal Information Form", the "Decision-Making Skills Scale", "Decision Rules Implementation Test", "Choices and Outcomes Activity" and semi-structured interviews developed by the researcher. The results of the study showed that the teachers needed information and guidance in terms of teaching decision-making, they experienced problems related to the curricula and families in the process, and approximately half of the students had difficulties in terms of defining-expressing decision-related problems. Additionally, in teaching decision-making, problems based on the teacher, the curricula and the families were experienced, and these problems had negative effects on the development of the decision-making skills of the students.
\end{abstract}

Keywords: Primary Education, Decision-Making Skills, Primary School Curriculum, Mixed Method Studies.

\section{Introduction}

Choices we make in our daily life from among options may be insignificant situations or turning points that direct our life. With a simple definition, decision-making is the choice of one of situations in cases where there are multiple options. A decision offers two or more options that are easy or not easy for the decision-maker to choose. In order to make the best decision, the decision-maker has to select one of these options or create a new option (Halpern, 1984 cited in Marzano et al., 1988). While deciding upon the option to be preferred, being aware of the situation one is in, gaining information about the options, assessment of the options and inquiring upon the situation are directly related to the suitability of the decision to be made.

The decision-making process includes several thinking skills such as critical, creative, analytical and dialectical thinking (Nardi \& Wales, 1985). There are more than 20 theories on decision-making in the literature. These are categorized as normative-rational decision theories, descriptive decision theories, both rational and descriptive decision theories and developmental decision theories (Çolakkadıoğlu, 2010). While normative decision theories explain how decisions should be made, descriptive decision theories explain who decisions are made in practice (Hansson, 2005). Normative decision theories state how decisions need to be made in a rational framework. However, the human factor, which is the decision-maker, is ignored here. Descriptive decision theories criticize normative decision theories at this point. They defend the idea that a person making a decision cannot always make decisions based on logic, and the context is important in the decision to be made, while they try to describe how people make decisions. Decision theories that are both descriptive and normative are based on theories that are in the two other categories and try to explain decision-making behaviors. Finally, a developmental decision theory argues that other theories dwell more on questions regarding the irrational decisions of adults, questions on whether or not decision-making skills develop by age are ignored, and it tries to find answers to such questions.

Mettas and Norman (2011), in their study where they examined decision-making and factors influential in development of decision-making, stated that curricula have a central role in development of decision-making skills. The teacher's implementation of the curriculum, perspective on learning-teaching and instruction materials and resources are variables that are affecting in developing the decision-making skills of children. Additionally, the child's age, peer effects, skills of transferring learning, strategies used in decision-making, motivation, information sources the child uses and assessment criteria are other variables that are influential on development of decision-making skills. Other variables that are influential on decision-making and development of decision-making skills are information, skills and values related to the own nature of decision-making or the issue of decision-making. Klaczynski et al. (2001) reported that decision-making cannot be explained alone by cognitive capacities such as intelligence, reasoning and using information, and real-life decisions are a combination of emotional and social-cognitive skills, values, beliefs and motivation.

At school, decision-making skills have a tendency to be taught via a topic, a class or a course. However, decision-making is a skill that goes beyond this tendency. Decision-making skills should be provided on all levels and in all curricula in an integrated, direct and clear way (Nardi \& Wales, 1985). In in-class activities for development of decision-making skills, realistic problem situations should be created. While making decisions on these problem situations, students should be ensured to use the steps of decision-making and assess 
their decisions. This way, permanent learning may take place. Some studies (Davidson, 1991; Hagen \& Hale, 1973; Howse et al., 2003) reported that difficulties of children in decision-making are related to their difficulties in collecting information relevant to the decision situation and assessing options. Children who encounter negative information in an option and are able to eliminate that option may make better decisions from among fewer options (Davidson, 1991). For this reason, while developing decision-making, paying careful attention to the steps of collecting information on the options and assessing the options contribute to the development of this skill. Studies have shown that skills of young children to assess options may be improved by training provided for them (Gelman, 1969; Howse, et al., 2003; Klaczynski, et al., 2001). Nardi and Wales (1985), and it is emphasized that decision-making is a complex process, and suitable materials need to be used in teaching it. In addition to this, students should be provided with open-ended problem situations and asked to reach the result by using the steps of decision-making. Development of thinking processes and skills is an important problem of education. Studies have shown that thinking is learnable and improvable (Doğanay, 2011). In this context, decision-making, which is a thinking skill, may also be learned.

As deficiency in decision-making skills at early ages will predict different behavioral problems (such as risky decision-making) in the later stages of life, the decision-making skills of children with weak skills in this aspect should be improved (Weller et al., 2014). Encouragement of the child to take a role in family-related decisions affects the development of the child's self-esteem, self-confidence and moral reasoning skills (Eccles at al., 1996). As individuals who make effective decisions and are satisfied with their decisions have high satisfaction from their lives, this skill should be provided to children from early ages (Cenkseven, 2012)

The National Council for the Social Studies [NCSS] collected the skills students need to gain in the social sciences under the title of "Skills Necessary for the Social Sciences" Johnson, 2010). One of such skills is decision-making. In effective citizenship education, decision-making and problem-solving are two important skills. Children of the age 11 need decision-making skills, and this age is a significant period in development of this skill (NCSS, 1998). In this context, it may be stated that it is important for these students to gain decision-making skills at primary schools.

Decision-making skills on the primary school level in Turkey are among the common skills included in the Turkish, Mathematics, Science and Technology, Social Studies and Social Sciences curricula put into practice in 2005 (MEB, 2008). Due to their visions, the curricula aim to train individuals with decision-making skills. Considering the curricula, it may be stated in general that not many targeted learning outcomes related to decision-making are included. In the Social Studies curriculum, which includes the highest number of outcomes, there is a total of 11 outcomes belonging to three years of education. The course on Social Sciences, which is the successor of the course on Social Studies and has an important position in citizenship education, does not include any targeted outcomes related to decision-making skills, while it states directly that it is a skill that is to be gained but does not go further than the topics of electing-being elected/voting

In the curricula put into practice in Turkey in 2018, these skills are included with two outcomes in each of the courses on Social Studies, Social Sciences and Human Rights and Citizenship and Democracy. There is no targeted outcome related to these skills in other curricula. In this context, it may be mentioned that, in comparison to the curricula in 2005, the place of decision-making skills among both contents and targeted outcomes has decreased even further with the curricula of 2018.
There is a need for studies that examine the factors effective on development of decision-making skills (curriculum, teacher, student, social environment, etc.) in detail, determine the problems experienced in the process and reveal the existing situation of students. It was determined that some studies in the literature on decision-making skills and development of these skills were in the form of descriptive studies (Goloğlu, 2009; Gömleksiz \& Kan, 2007; Karakaş Günal, 1999; Kaşkaya et al., 2017; Öncül, 2013; Tekin \& Ulaş, 2016) and had experimental designs (Akdaş, 2013; Bronstein, 1992; Çakmakçı, 2009; Kardaş, 2013; Köseoğlu, 2013; Nicolaou et al., 2009; Tetik, 2013). Among these studies, it was observed that a comprehensive work was not carried out towards the effectiveness of existing curricula, problems that are experienced and solution recommendations, the effectiveness of different methods on development of decision-making skills was examined in general, and the existing curricula were used as the control variables. For these reasons, it is believed that a study that comprehensively examines the factors effective in the development of decision-making, problems that are experienced in the process and the existing situation of students with a mixed method will contribute to the literature.

The purpose of this study is to investigate the decision-making skills of fourth-grade students based on student and teacher views. For this general purpose, answers were sought for the following questions.

\section{What are classroom teachers'}

a. Views on the decision-making skills of primary school students,

b. Practices of development of the decision-making skills of primary school students and

c. Problems regarding teaching decision-making skills and solution recommendations about these problems?

2. What is the state of the decision-making skills of primary school fourth-grade students based on the data obtained from
a. The Decision-Making Skills Scale,
b. Decision Rules Implementation Test and
c. Choices and Outcomes Activity?

\section{Method}

\section{Research Design}

This study adopted a mixed method. A mixed method is a unique method that may be used in answering research questions of qualitative and quantitative methods within the same study (Tashakkori \& Teddlie, 2010). This study employed the method of "convergent parallel design" (Creswell \& Plano Clark, 2014). In this design, qualitative and quantitative methods are used simultaneously and have equal statuses. The data are analyzed separately, and the findings are combined, compared and interpreted (Creswell \& Plano Clark, 2014). This study aimed to both obtain in-depth information and make a generalization. The process that was followed in the study is shown in Figure 1.

The qualitative data of the study were collected with semi-structured interviews (teachers) and the "Choices and Outcomes Activity" (students), and content analysis was carried out. The quantitative data were collected by the "Decision-Making Skills Scale" and the "Decision Rules Implementation Scale" developed by the researchers, and the data obtained from the De- 


\begin{tabular}{|c|c|c|c|c|c|}
\hline Stages & Stage I & Stage II & Stage III & Stage IV & Reporting \\
\hline Activities & $\begin{array}{l}\text { - Semi-structured interviews } \\
\text { with teachers } \\
\text { - Application of qualitative } \\
\text { measurement instruments } \\
\text { with students }\end{array}$ & - Content analysis & $\begin{array}{l}\text { - Sample Selection } \\
\text { - Application of } \\
\text { measurement } \\
\text { instruments }\end{array}$ & $\begin{array}{l}\text { - Descriptive } \\
\text { statistical analyses } \\
\text { - Analysis of Variancé }\end{array}$ & $\begin{array}{c}\text { Qualitative- } \\
\text { Quantitative Findings }\end{array}$ \\
\hline
\end{tabular}

Figure 1. Research Process

cision-Making Skills Scale were relationally compared. The qualitative and quantitative findings were discussed together.

\section{Sample}

The participants of the study consisted of 9 classroom teachers who had served / were serving as $4^{\text {th }}$ grade teachers and $5434^{\text {th }}$ grade students from different socioeconomic levels in the province of Eskisehir in Turkey. The purposive sampling method of maximum diversity sampling was used to determine the students to be included in the study. In order to optimally represent the population, students were selected from lower (179), medium (191) and higher (173) socioeconomic levels. In the pilot interviews, it was seen that the interviewed teachers were not sufficiently knowledgeable regarding decision-making skills and experienced problems in providing opinions regarding the topic. This is why the participating teachers were selected as those who had postgraduate degrees. In addition to this, in order to be able to discover different points of view, attention was paid to select the teachers from schools with different socioeco-

Table 1. Information on the interviewed teachers

\begin{tabular}{|c|c|c|c|}
\hline Participant* & Seniority & $\begin{array}{l}\text { Experience of Teaching Fourth Grade (after } \\
\text { 2005) }\end{array}$ & Educational History \\
\hline Duru & 12 years & 2 times & $\begin{array}{l}\text { Bachelor's: Form Teaching } \\
\text { Master's: Form Teaching } \\
\text { PhD: Research methods and statistics }\end{array}$ \\
\hline Beste & 6 years & 2 times & $\begin{array}{l}\text { Bachelor's: Form Teaching } \\
\text { Master's: Form Teaching } \\
\text { PhD: Form Teaching (ongoing) }\end{array}$ \\
\hline Fatma & 18 years & 1 time & $\begin{array}{l}\text { Bachelor's: Form Teaching } \\
\text { Master's: Educational administration and inspection PhD: } \\
\text { Form Teaching }\end{array}$ \\
\hline Esra & 5 years & 2 times & $\begin{array}{l}\text { Bachelor's: Form Teaching } \\
\text { Master's: Form Teaching } \\
\text { PhD: Form Teaching (ongoing) }\end{array}$ \\
\hline Derya & 14 years & 2 times & $\begin{array}{l}\text { Bachelor's: Form Teaching } \\
\text { Master's: Form Teaching }\end{array}$ \\
\hline Ahmet & 5 years & 1 time & $\begin{array}{l}\text { Bachelor's: Form Teaching } \\
\text { Master's: Form Teaching } \\
\text { PhD: Form Teaching (ongoing) }\end{array}$ \\
\hline Aslı & 13 years & 3 times & $\begin{array}{l}\text { Bachelor's: Form Teaching } \\
\text { Master's: Form Teaching }\end{array}$ \\
\hline Hasan & 13 years & 2 times & $\begin{array}{l}\text { Bachelor's: Form Teaching } \\
\text { Master's: Educational administration and inspection PhD: } \\
\text { Form Teaching (ongoing) }\end{array}$ \\
\hline Mustafa & 11 years & 3 times & $\begin{array}{l}\text { Bachelor's: Form Teaching } \\
\text { Master's: Form Teaching } \\
\text { PhD: Philosophy of education (ongoing) }\end{array}$ \\
\hline
\end{tabular}

nomic backgrounds. Table 1 shows the seniority, experience of teaching fourth grade and their educational history of the teachers who were interviewed.

\section{Research Instruments and Procedures}

Explanations regarding the instruments that were used for data collection in the study are given under different titles.

\section{Student personal information form}

This form included items that collected information on the age, sex of the students, number of siblings in the family and whether or not the students' opinions were included at school and in family.

\section{Decision-making skills scale}

The scale was developed by the researchers with the purpose of determining the decision-making skills of students. The factor loads of the 15 items under a single factor in the scale varied between .53 and .74, its Cronbach's alpha relia- 
bility coefficient was .89, and it explained $40.078 \%$ of the total variance. The goodness of fit indices of the model tested with CFA were within acceptable limits as $X^{2} / \mathrm{df}$ : 2.02, RMSEA: .075, RMR: .030, SRMR: .059, NFI: .93, NNFI: .96, CFI: .97, GFI: .88 and AGFI: .85 (See Sever \& Ersoy, 2019).

\section{Decision rules implementation test}

The test was used to examine the skills of students to implement decision rules. In the case-based test, the student is expected to reach a decision by assessing criteria. The student who examines the comparison table containing the different features of three products is asked to make a decision based on the situations given in the questions. The test also included an open-ended question that allowed obtaining qualitative data on the decision-making process of the student. The test was developed by utilizing the psychometric test that was developed by Weller, Levin, Rose and Bossard (2012) for examining the decision-making skills of children at ages 10-11. In order to determine the validity and reliability of the test, item total correlations, upper-lower \% 27 points scores and Cronbach Alpha were examined. Item total correlations ranged from .40 to .61 and upper-lower \%27 points scores were significant $(p<.001)$. Cronbach Alpha coefficient was calculated as .72.

\section{Choices and outcomes activity}

The activity was utilized to obtain qualitative information about examination of the decision-making behavior of the student. While developing the activity, the student activities in the decision-making program of the "Road to Success (www. roadtosuccess.org)" initiative was utilized. The activity was developed for the purpose of data collection and examination about skills of being aware of - defining the decision situation and possible options, being able to create alternatives and being able to predict possible outcomes of choices.

Semi-Structured Interview Form: The form was developed for the interviews carried out with the teachers. With the form, it was aimed to reveal the factors effective in the development of skills of decision-making and problems related to the process. The semi-structured interview form that was prepared was tried out in a pilot implementation after being submitted for expert opinion and subjected to necessary adjustments. It took its final firm with the adjustments that were made after the pilot application.

\section{Data Analysis}

For the purpose of making sense of raw data obtained from the interviews with the teachers, revealing patterns and analyzing them, content analysis was used, and the results were grouped under themes. Boyatzis (1998) defined content analysis as a method that is used for defining, analyzing and reporting the patterns (themes) in raw data and expressed it as the process of coding qualitative information. The semi-structured interview form that was developed as a result of obtaining expert opinions and pilot implementations was used in the interviews that were conducted with the teachers.

Before the interviews, the participating teachers were firstly given informed consent forms, and the necessary explanations about the process was made. The interviews were recorded by using an audio recorder and then transcribed. Direct quotes were included to achieve reportability, and purposive sampling was utilized in determination of the participants. For confirmability, raw data and analyses were subjected to expert opinion. The same procedures were repeated for the qualitative data obtained from the students with the case-based activity.

In the process of developing the Decision-Making Scale, the literature was reviewed, items of behavior indicating the aforementioned skill were formed, and the scale's structure was presented by exploratory and confirmatory factor analyses. After this, analyses on the validity and reliability of the scale were carried out. For the purpose of making relational comparisons with the data obtained from the measurement instruments that were developed, analysis of variance (t-test, One-way ANOVA) was carried out, and additionally, descriptive statistics were examined. Finally, the qualitative and quantitative findings that were obtained were combined and discussed in a comprehensive approach.

\section{Results}

Views of Classroom Teachers on the Decision-Making Skills of Primary School Students

Regarding the decision-making skills of primary school students, the teachers mentioned the factors influential on the development of decision-making, difficulties experienced in decision-making and the developmental processes of decision-making. These dimensions are shown in Figure 2.

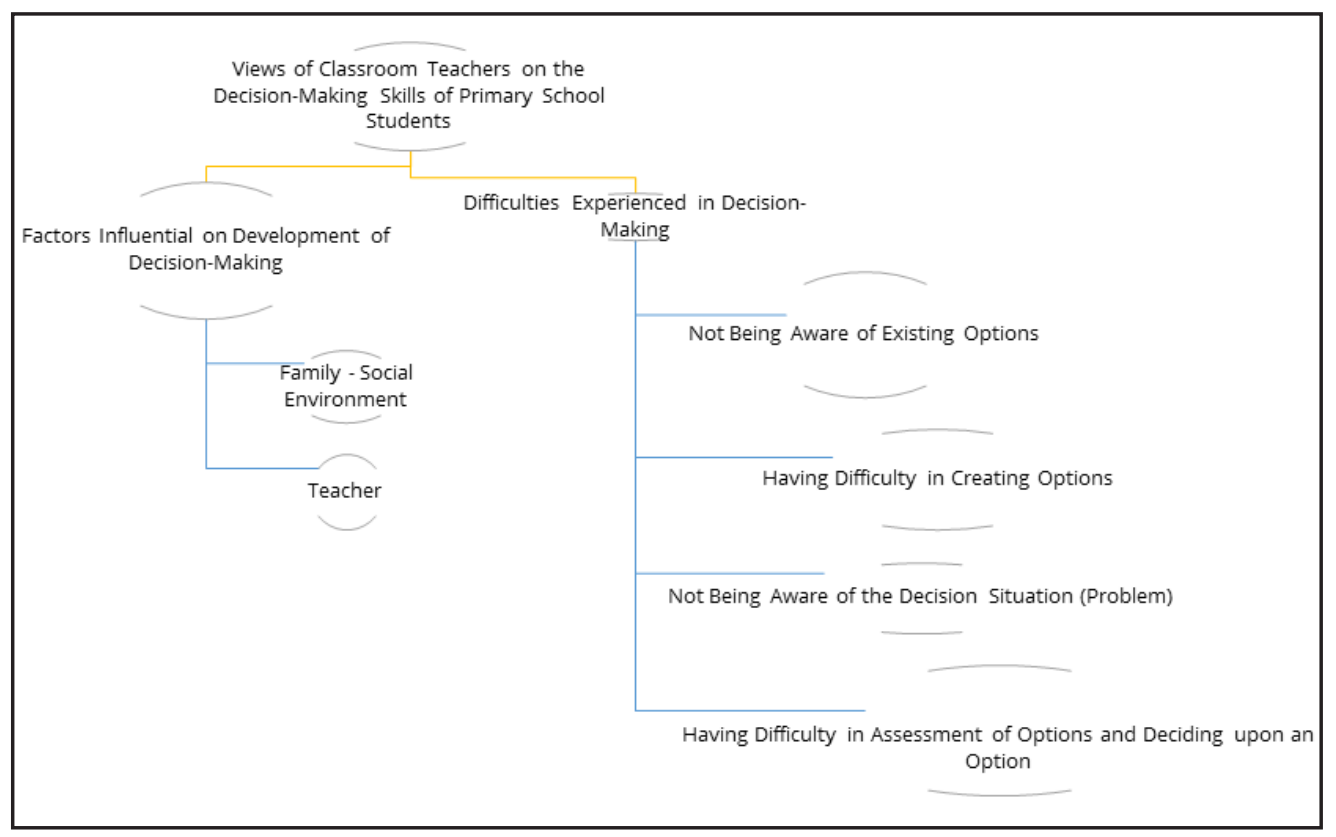

Figure 2. Views of classroom teachers on the decision-making skills of primary school students 
According to the statements of the teachers, the factors that are influential on the development of decision-making skills consist of the dimensions of family - social environment and the teacher. These dimensions provide the child with experiences such as "creating decision-making experiences for the child / including the child in decision-making processes", "bringing up the child in a democratic environment / allowing the child to self-express." The family, the teacher and the social environment have a common role in the development of the decision-making skills of the child. Teacher opinions regarding this issue are presented below:

I believe, when there is an authoritarian teacher, the child, who grows up in a classroom where everything is decided upon by the teacher, cannot make their own decisions or in a home where only the decisions of the mother or the father are valid without sharing a thought, will not be able to make much affective decisions and will be completely dependent, unable to make their own decisions. Social environment is the same, just like friendship structures. They are all pillars of this issue. (Ahmet)

If the family environment is a democratic setting, this helps the child understand what decision-making is. However, if the family is not a democratic place but a place where only one authority is dominant, the child cannot make decisions. As someone, somehow makes decisions for the child, the child becomes either dissatisfied or used to a given situation. (Mustafa)

According to the teacher opinions above, being able to make their own decisions in the school, family and social environment by the child, as well as the child's participation in decision-making processes, are effective in the development of the decision-making skills of the child. In addition to this, the teachers mentioned that the factors that are effective in the development of decision-making should be considered together. In order for thinking skills to develop, thinking opportunities should be created for individuals. Considering that experiences have significant effects on learning, it may be stated that development of decision-making skills, among thinking skills, will be positively influenced by the experiences of the child. In achievement of these thinking experiences, democratic and thought-friendly environments have a critical significance. Furthermore, the idea that the family is firstly effective in development of decision-making skills, and the teacher is a complement of this was expressed, and it was stated that there is not much possibility of intervening with the family. A teacher opinion regarding the issue is shown below:

Family first... It comes from the family anyway. Things that are thought in primary school stay ambiguous if they are not supported in the family. Let us say, we are discussing democracy in the family, discussing the decision-making process. Do you attend decisions in your family, do they take your opinion, let us say, did you provide your opinion while registering for this school? If most students say 'no', it is already not possible to establish democracy in the family. We might be able to establish the idea of in-school democracy, but if we take on the concept of democracy and the decision-making process as a whole, you cannot interfere with the family much, maybe with family trainings, but to a limited extent. (Fatma)

According to Fatma, the school environment may be relatively improved by teachers, but the desired productivity cannot be obtained from the system as the teacher cannot be effective in the family environment, and the problems in the family environment cannot be solved. Considering that the family, the social environment and the teacher have a mutual effect on the development of the decision-making skills of the child, it may be stated that it is necessary to have a comprehensive point of view towards the solution of current problems.

In terms of the problems experienced in decision-making, the classroom teachers thought that students are not aware of the options they have, and they experience problems in terms of creating options. They argued that students should be provided with a framework about the decision situation by providing them with relevant options. Teacher opinions regarding this issue are presented below:

You should provide some options. I believe students should be guided, especially at early ages. There should be a limitation, and I observe they are not much aware of this at early ages anyway. ...but at later ages, coming to the fourth grade, I have actually also taught fifth graders, they become more aware of their options, and they start to inquire more. (Beste)

They cannot analyze different situations in their heads, or they only make a choice from only among the given situations. That is, it is definitely being needed to provide them with options. (Mustafa)

Additionally, it was stated that difficulties in decision-making are observed more frequently in situations related to daily life - practice:

It is relatively better in classes as we constantly see this is math ematics, this is Turkish and all, but when we come to their socia lives, when we ask for an action towards putting the situation into practice for a different thing, there is more interruption there. (Mustafa)

In the quotes above, the teachers emphasized that students are not aware of the existing options for decision situations, and they have difficulty in creating options. This is possible considering the ages and developmental characteristics of students. Drawing a framework of the decision situation may be useful in activities to be carried out with students. Nevertheless, in addition to this, encouraging students to create other options outside the existing options and including these in activities may affect the decision-making skills of the child positively.

The teachers stated that students experience difficulties in understanding the decision situation, examining options and deciding upon an option. Moreover, it was also stated that students consider criteria that are not related to the decision situation and do not have an idea about the decisions they make. Teacher opinions regarding this issue are presented below:

Why was this decision made? Nope, there is only a decision, they made it. This is the only noticeable thing. (Mustafa)

While selecting a person for a position like a class prefect or library staff, instead of choosing individuals who can do that job, they get influenced by their friends such as selecting a friend they like, being concerned that this person would be offended if not selected, that person likes this and that... (Aslı)

The teachers thought that students are likely to accept decisions being made for them, they avoid making decisions and experience indecisiveness. Teacher opinions regarding this issue are presented below:

Students usually want someone to make decisions instead of them. I guess, you know, they choose the easy way. It makes them happy when the other kid makes decisions instead of themselves. (Ahmet)

There is a situation like they do not want to make a decision first, they want their teacher or friend to make a decision. When they make a decision, they are not actually decisive either. They make decisions, but they show an attitude like they could immediately change their response, their decision. (Duru)

While the difficulties mentioned above that are experienced by children in decision-making are suitable for their ages and developmental characteristics, it may be considered that the deficiency of the child in decision-making is effective on the emergence of the aforementioned difficulties. In 
parallel to this idea, the teachers stated the reasons that could be effective in the emergence of these problems as failure to create decision-making experiences for students, exclusion of students from decision-making processes and failure to provide a democratic environment for students. Teacher opinions regarding this issue are presented below:

There are incredible students. Those who make the correct, ap propriate decisions... They say they want to take this course, there are courses of 3 credits, 4 credits. They say, if they take this for 2 hours, they could take that for 3 hours. ... but when the child goes home, the family says no, you will not take that course. I believe family is very influential, not only for school life. The child chooses their friends, they decide to do something together, but the family does not let them. Their future lives turn into a situation of 'no matter what I decide upon. Others are deciding for me.' That have to live based on other people's truths. They turn into individuals with lack of self-esteem, those who are dependent on others' de cisions. (Beste)

...their ideas have not been asked. Children have always lived in a stable, fixed manner. This is why children do not bother getting into a mentality on how they could make decisions here, how they could follow a different path. (Esra)

According to the teacher views above, protective and author itarian attitudes are observed in families. Authoritarian and protective family attitudes lead to issues such as failure to provide the child with a democratic environment, deprivation of the child from decision experiences and taking responsibility and lack of respect for the decisions - views of the child. Such situations may have a negative effect on the development of the decision-making skills of the child.

Practices of Classroom Teachers towards Development of the Decision-Making Skills of Primary School Students

The dimensions of the practices of classroom teachers towards development of the decision-making skills of primary school students are shown in Figure 3.

\begin{tabular}{|c|c|c|c|}
\hline & $\begin{array}{r}\text { Practices towards D } \\
\text { Mak }\end{array}$ & ment of Decision- & \\
\hline $\begin{array}{l}\text { Giving Responsibility, } \\
\text { Encouraging Decision- } \\
\text { Making. }\end{array}$ & $\begin{array}{l}\text { Providing Democratic } \\
\text { Environment }\end{array}$ & $\begin{array}{l}\text { Interdisciplinary } \\
\text { Practices }\end{array}$ & $\begin{array}{l}\text { Practices Directly on } \\
\text { Decision-Making Skills }\end{array}$ \\
\hline
\end{tabular}

Figure 3. Practices of classroom teachers towards development of the decision-making skills of primary school students

While developing the decision-making skills of students, the classroom teachers gave them responsibility and encourage them to make decisions. Teacher opinions regarding this issue are presented below:

First of all, I absolutely support the decisions they make and try to guide them in this matter by speaking to both them and their families for students to be always able to make their own decisions. (Duru)

In the simplest example, when we are about to create a food list, we submit it for a vote. Other than this, I have practices of electing a classroom representative every month each year. (Hasan)

The teacher views given above show that, while improving their decision-making skills, the classroom teachers provided students with opportunities to make their own decisions and encourage them to make decisions. While this practice is important in terms of providing students with decision-making experiences, it will not be sufficient in development of the skill. It is important that the decision opportunities created towards improvement of this skill contain decision-making steps. In experiences of decision-making, it is important to employ thinking-related activities on what the situation to be decided upon is, what the existing options are - whether or not an option outside these options can be created, what the positive and negative aspects of options are, utilization of previous experiences while decision-making and assessment of the selected option in the process.

The teachers believed that creating a democratic setting where students can express their opinions is important in the development of this skill. The participating teachers provided students with a democratic environment to improve their decision-making skills. An example of opinions about this issue is given below:

I try to provide a democratic classroom environment. We try to get their opinions and make them aware that their opinions are important for us. We try to establish the idea that they can also have an opinion, and this should be so in the family, too. While de termining classroom rules, when we include students in the decision, the child is already taking responsibility for something that is decided upon together. That is, if you include children in such processes, it is easier for them to adopt it and internalize it. (Fatma)

In the quote above, the teacher stated that she created a democratic classroom environment. A democratic classroom environment where students can express their opinions is important in development of thinking skills. However, these environments should be guided with purposive activities towards development of thinking skills. It may be seen in the quotes below that purposive activities were usually not used in development of this skill. In development of the decision-making skills of students, the teachers mostly resorted to multidisciplinary practices rather than activities directly about decision-making. Teacher opinions regarding this issue are presented below:

Not as an in-person training, but we provide it in the presented environment and within other skills we mentioned. ...in naturally developing processes. (Aslı)

I think it is a process. For example, we have guidance counselling courses and some values in these courses. When we discuss these values, I include this skill in this topic. You know, they say multidisciplinary, like utilizing mathematics in Turkish courses. (Derya)

Based on the quotes above, the teachers usually did not utilize purposive activities towards improving decision-making skills, they took on decision-making skills superficially, and they even reduced decision-making to activities such as allowing the student to speak or vote. As an exception to this situation, two teachers reported that they conducted activities directly related to decision-making steps. Teacher opinions regarding this issue are presented below:

There was a guidance counselling course last year. We had good activities in relation to this. A psychological counsellor, a guidance counsellor was visiting in relation to decision-making. We could conduct some activities with them and the students. We conducted relevant activities with the guidance counsellor up to the first 3 grades. Not like the activities in the curriculum, but there were some activities towards developing this skill in the field of psychological guidance and counselling. (Beste)

For example, they worked for about a week in preparation for the activity 'the program on which channel is suitable for us', they watched television. Then, they decided upon the program that was suitable for themselves. In Social Sciences, there is the topic of 'my needs and wants'. For example, what to decide on first? Their needs, or their wants? There have been practices towards implementing their decision-making skills about these issues. (Beste)

According to the teacher views above, the said teacher used more specialized activities towards decision-making. These activities were purposive activities that included steps of decision-making and aimed to develop decision-making skills. It may be stated that using such activities in developing decision-making skills would be more effective. 
Problems Experienced by Classroom Teachers in Teaching Decision-Making Skills and Solution Recommendations

Figure 4 shows the dimensions of teacher opinions on the problems they experienced regarding teaching decision-making skills.

The teachers stated that decision-making skills were not clear in the curricula, they did not encounter many activities, and they did not have awareness of the place of this skill in the curriculum. Teacher opinions regarding this issue are presented below:

I did not encounter an activity that included decision-making skills. I do not know, maybe I am not aware of it. (Ahmet)

In the quote above, the teacher stated that he did not encounter an activity related to decision-making. There are, although a few, activities related to decision-making in curricula. The reason for this result may be the lack of clear explanation of decision-making in curricula and the failure in raising awareness in teachers regarding this skill.

In the curricula, it was expressed that decision-making would be taken on with an interdisciplinary approach, but no sufficient information was included about teaching it. Whether or not the existing activities were related to decision-making could not be identified by the teachers. It was believed that the necessary importance could not be paid to decision-making skills which were discussed based on a multidisciplinary approach, and this skill was allowed to slide in the course of the education process. The following quotes also agreed with this situation.

There are examples I did in this topic, you know, towards improving the decision-making skills of children. I do not think many teachers would sit down, think of developing the decision-making skills of children and conduct such activities. I do not think there is such an awareness either. (Ahmet)

Maybe, the teacher also does not think that they are developing decision-making skills while teaching it, maybe it is a naturally developing process. (Aslı)

The teachers stated that they needed guidance and information processes regarding decision-making, and the curricula did not guide them. Teacher opinions regarding this issue are presented below:

The teacher thinks it is very important for the student to make decisions, but the teacher needs to be guided in order to know how the student should do so, with which activity and in which course the student is involved in they could do this the right way. I do not think there are many clear explanations. This is also applicable for other skills, too. (Beste)
It is provided to children in general in the curriculum, but what to do specifically for it, this is more ambiguous. (Ahmet)

Similarly to the statements of the teachers, the curricula did not provide sufficient explanations regarding teaching decision-making skills. The teachers who did not have knowledge about how to provide this skill stated that they experienced problems in the process. In addition to this, the teachers also stated that there were shortcomings in the curricula regarding targeted outcomes and activities towards development of decision-making skills. Teacher opinions regarding this issue are presented below:

When I look at the curricula, I do not think there are many targeted outcomes within the course towards decision-making skills. There may be related outcomes, but I do not remember having reported an outcome directly related to decision-making skills. (Ahmet)

Considering especially the Social Sciences curriculum, I look at the topics as a fourth-grade teacher. In fact, activities towards the decision-making in students may be carried out in many topics, but when I look at the outcomes, I do not see many. (Beste)

Decision-making skills should be more noticeable in the curricula, and directly related activities should be included... (Aslı)

In the curricula, decision-making skills are among the skills that need to be directly provided with a multidisciplinary approach. However, considering these curricula, it may be stated that sufficient information is not provided on what decision-making is, how instruction of it should be carried out and how it should be assessed. In addition to this, it may also be stated that there are not sufficient targeted outcomes and activities related to decision-making. All problems stated by the teachers regarding teaching decision-making on a curricular level were in agreement with this situation.

In the dimension of the problems experienced in teaching of decision-making, the teachers also mentioned problems experienced due to families and the environment in addition to those originating from the curricula. The teachers believed that the family and the environment had negative effects on the development of the decision-making skills of students. This negative effect is in the form of failure to provide a democratic setting where the child can express opinions in the family and social environment, lack of collaboration of the family with teachers in development of these skills and lack of support for the teacher. Teacher opinions regarding this issue are presented below:

...social environment, parents, I believe these are influential. The child learns something at the school for four-five hours, but the existing order continues in the family. The child takes what they see from their mother and father. (Ahmet)

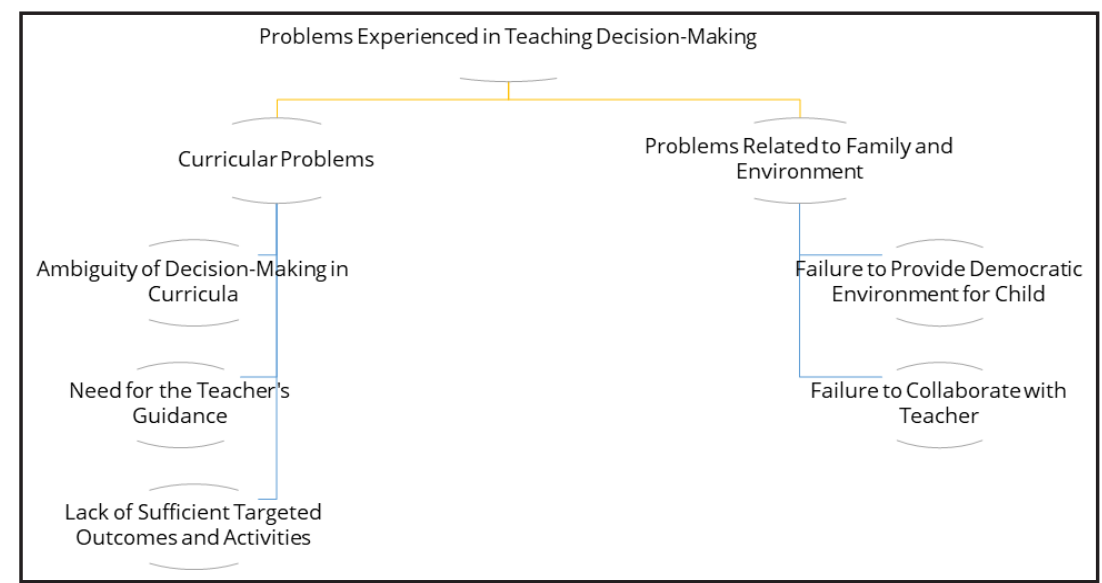

Figure 4. Views of classroom teachers on the problems experienced in teaching decision-making skills 
The student is very aware, conscious, makes decisions, you make decisions together, but after a day, you see that the family has obstructed it. This interrupts my instruction process. This is a problem that we have not managed to establish a view mutually with the family. (Beste)

In development of decision-making skills, it is important to provide a democratic setting for the child where the child can express their ideas and create decision-making experiences for the child. In achievement of these environments at and outside the school, it is needed for teachers and families to collaborate for decision-making skills to be developed.

The recommendations of the teachers regarding development of decision-making skills and solutions of the problems experienced in this process are given in Figure 5.

The teachers stated that it would be useful for them to receive training regarding decision-making skills. Teacher opinions regarding this issue are presented below:

The professional capacities of teachers may be investigated. In order for the decision-making skills of a child to develop, firstly the coordinator of that curriculum should be able to achieve this. The teacher may be informed in this sense. (Esra)

Training teachers is highly important. For example, the curricula changed in 2005 for teachers, but they did not receive any proper training on how to apply these curricula. (Fatma)

The teachers reported that the curricula did not guide them, they had lack of knowledge regarding decision-making, and they did not have awareness of the issue. As seen in the quotes above, the teachers thought that they needed training to overcome the aforementioned shortcomings. Additionally, some of the teachers mentioned that awareness should be raised in families regarding provision of a democratic environment for the child.

Firstly, family education is important. For a child who grows up in a healthy, democratic family in a setting where they can participate in decisions, what we do here is merely adding onto what the child already has. However, if the child has not seen such things, what we do here becomes meaningless. (Fatma) One teacher among the participants stated that there should be cooperation with whoever is around the child in terms of development of this skill by formation of a mutual opinion with them as the following:
In fact, there is a need to form a collaboration, a common view for this skill. With whom? The family, the child's environment, their teacher. Actually, with whoever it is that is involved in the child's life. (Beste)

The teachers emphasized the importance of providing the child with environments that will develop decision-making skills. A teacher stated that there is a need for the child to express themselves freely in these democratic environments as the following:

I believe a democratic environment is especially very important in development of decision-making skills. The child would not be able to express their decision when such an environment is not provided. I want to mention the importance of a liberal setting where the child could express decisions. (Hasan)

The teachers' curriculum-related recommendations in development of decision-making skills were as clear definition of skills in curricula, making explanations on how to provide these skills, association of skills with more targeted outcomes and activities and making explanations on how to measure skills. Teacher opinions regarding this issue are given below:

The teacher should be guided within the curriculum. Teachers need a guide in teaching skills. That is, for example, what is this skill? These skills can be defined. More targeted outcomes... That is, a skill is not something that can be gained or measured with three targeted outcomes. More outcomes could be formed. For example, how will we measure whether or not this skill is gained? do not think the instruction process is much clear. (Beste)

There may be more activities, different, interesting activities. Not every teacher can produce these activities, because they are not creative, or they cannot or would not spare time for them. (Mustafa)

In the theoretical part of the study, some assessments were made regarding the place of decision-making skills in the curricula. It was observed that these assessments and teacher opinions were in agreement. In this context, it is seen important to make the decision-making skills in curricula much clearer, represent the skill with more targeted outcomes and activities and guide teachers in this direction.

Findings on the Decision-Making Skills of Primary School Fourth Grade Students

This section presents the findings obtained from the quantitative data.



Figure 5. Recommendations on development of decision-making skills and solution of problems 
The $t$-test results on the scores of the students in the Decision-Making Skills (DMS) Scale based on their sexes are given in Table 2.

Table 2. $t$-test results on the DMS scale scores based on sex

\begin{tabular}{lrrrrrr}
\hline Sex & $N$ & $M$ & SD & DF & $t$ & $p$ \\
\hline Female & 275 & 50.31 & 7.09 & 537 & 3.427 & $.000^{*}$ \\
\hline Male & 264 & 48.14 & 7.58 & & & \\
\hline${ }^{*} p<.01$ & & & & & &
\end{tabular}

The results of the analysis showed that the scores of the students in the scale differentiated significantly based on sex $\left(t_{(537)}=3.427, p<.01\right)$. The female students $(M=50.31)$ had a significantly higher mean score than the male students $(M=$ 48.14).

The $t$-test results on the scores of the students in the Decision Rules Implementation (DRI) Test based on their sexes are given in Table 3.

Table 3. $t$-test results on the DRI test scores based on sex

\begin{tabular}{lrrrrrr}
\hline Sex & $N$ & $M$ & SD & DF & $t$ & $p$ \\
\hline Female & 275 & 6.69 & 1.60 & 537 & -.016 & .987 \\
\hline Male & 264 & 6.67 & 1.67 & & & \\
\hline
\end{tabular}

The scores of the students in the test did not differ significantly based on their sex. When the mean scores were compared, it was seen that the scores of both the boys and the girls were almost equal.

Table 4 shows the descriptive statistics of the students in the DMS Scale, while Table 5 shows the results of the one-way analysis of variance (ANOVA) based on age.

Table 4. Descriptive statistics of the scores in the DMS scale based on age

\begin{tabular}{lrrr}
\hline Age & $N$ & $M$ & SD \\
\hline 9 & 145 & 48.97 & 7.30 \\
\hline 10 & 366 & 49.40 & 7.48 \\
\hline 11 & 29 & 49.07 & 7.29 \\
\hline
\end{tabular}

Table 5. ANOVA results of the scores in the DMS scale based on age

\begin{tabular}{lrrrrrr}
\hline $\begin{array}{l}\text { Source of } \\
\text { Variance }\end{array}$ & $\begin{array}{r}\text { Sum of } \\
\text { Squares }\end{array}$ & DF & $\begin{array}{r}\text { Mean } \\
\text { Squares }\end{array}$ & $F$ & $p$ & $\begin{array}{l}\text { Significant } \\
\text { Difference }\end{array}$ \\
\hline $\begin{array}{l}\text { Inter- } \\
\text { group }\end{array}$ & 21.119 & 2 & 10.560 & .191 & .826 & \\
\hline $\begin{array}{l}\text { Intra- } \\
\text { group }\end{array}$ & 29624.705 & 537 & 55.167 & & & \\
\hline Total & 29645.824 & 539 & & & & \\
\hline
\end{tabular}

When the scores in the DMS scale were examined based on the variable of age, no significant differentiation was observed. Based on this finding, it may be stated that, for the same grade level, the variable of age was not a significant variable in terms of DMS scale scores.

Table 6 shows the descriptive statistics of the students in the DRI Test, while Table 7 shows the results of the one-way analysis of variance (ANOVA) based on age.

Table 6. Descriptive statistics of the scores in the DMS scale based on age

\begin{tabular}{lrrr}
\hline Age & $N$ & M & SD \\
\hline 9 & 145 & 6.74 & 1.65 \\
\hline 10 & 366 & 6.67 & 1.63 \\
\hline 11 & 29 & 6.86 & 1.48 \\
\hline
\end{tabular}

Table 7. ANOVA results of the scores in the DMS scale based on age

\begin{tabular}{lrrrrrr}
\hline $\begin{array}{l}\text { Source of } \\
\text { Variance }\end{array}$ & $\begin{array}{r}\text { Sum of } \\
\text { Squares }\end{array}$ & DF & $\begin{array}{r}\text { Mean } \\
\text { Squares }\end{array}$ & $F$ & $p$ & $\begin{array}{l}\text { Significant } \\
\text { Difference }\end{array}$ \\
\hline $\begin{array}{l}\text { Inter- } \\
\text { group }\end{array}$ & 1.311 & 2 & .656 & .248 & .780 & \\
\hline $\begin{array}{l}\text { Intra- } \\
\text { group }\end{array}$ & 1418.487 & 537 & 2.642 & & & \\
\hline Total & 1419.798 & 539 & & & & \\
\hline
\end{tabular}

When the scores in the DRI test were examined based on the variable of age, no significant differentiation was observed. Based on this finding, it may be stated that, for the same grade level, the variable of age was not a significant variable in terms of DRI test scores.

The t-test results on the scores of the students in the DMS scale based on the number of children in their families are given in Table 8.

Table 8. DMS scale t-test results based on the number of children in families

\begin{tabular}{lrrrrrr}
\hline Number of Children & $N$ & $M$ & SD & DF & $t$ & $p$ \\
\hline One or Two & 442 & 49.55 & 7.42 & 534 & 2.116 & $.035^{*}$ \\
\hline More than Two & 94 & 47.76 & 7.48 & & & \\
\hline$* P<.01$
\end{tabular}

${ }^{*} p<.01$

The results of the analysis showed that the scores of the students in the scale differentiated significantly based on the numbers of children in their families $\left(t_{(534)}=2.116, p<.05\right)$. Accordingly, the children with no siblings or one sibling in their family $(M=49.55)$ had a higher mean score than those with two or more siblings $(M=47.76)$.

The t-test results on the scores of the students in the DRI test based on the number of children in their families are given in Table 9.

Table 9. DRI test t-test results based on the number of children in families

\begin{tabular}{lrrrrrr}
\hline Number of Children & $N$ & $M$ & SD & DF & $t$ & $p$ \\
\hline One or Two & 442 & 6.81 & 1.57 & 534 & 3.873 & $.000^{*}$ \\
\hline More than Two & 94 & 6.10 & 1.77 & & & \\
\hline${ }^{*} p<.01$
\end{tabular}

The results of the analysis showed that the scores of the students in the scale differentiated significantly based on the numbers of children in their families $\left(t_{(534)}=3.873, p<.01\right)$. Accordingly, the children with no siblings or one sibling in their family $(M=6.81)$ had a higher mean score than those who had two or more siblings $(M=6.10)$.

Table 10 shows the descriptive statistics on the scores of the students in the DMS Scale, while Table 11 shows the results of the one-way ANOVA on the scores based on socioeconomic levels.

Table 10. Descriptive statistics on the scores of the DMS scale based on socioeconomic levels

\begin{tabular}{lrrr}
\hline Socioeconomic Level & $N$ & $M$ & SD \\
\hline Higher & 173 & 48.06 & 7.45 \\
\hline Medium & 191 & 51.32 & 7.20 \\
\hline Lower & 179 & 48.13 & 7.27 \\
\hline
\end{tabular}

According to the results of the ANOVA, it was observed that the DMS scale scores differentiated significantly based on socioeconomic levels $\left(F_{(2-540)}=12.073\right)$. According to the results of the Scheffe test that was carried out to determine the groups between which this difference was obtained, it 
may be stated that there was a significant difference between the medium and higher and between the medium and lower socioeconomic levels in the favor of the mid-level socioeconomic status.

Table 11. ANOVA results on the scores of the DMS scale based on socioeconomic levels

\begin{tabular}{lrrrrrr}
\hline $\begin{array}{l}\text { Source of } \\
\text { Variance }\end{array}$ & $\begin{array}{r}\text { Sum of } \\
\text { Squares }\end{array}$ & DF & $\begin{array}{r}\text { Mean } \\
\text { Squares }\end{array}$ & $F$ & $p$ & $\begin{array}{l}\text { Significant } \\
\text { Difference }\end{array}$ \\
\hline $\begin{array}{l}\text { Inter- } \\
\text { group }\end{array}$ & 1287.018 & 2 & 643.509 & 12.073 & $.000^{*}$ & Mid-High \\
\hline $\begin{array}{l}\text { Intra- } \\
\text { group }\end{array}$ & 28782.535 & 540 & 53.301 & & & Mid-Low \\
\hline Total & 30069.553 & 542 & & & & \\
\hline${ }^{*} p .01$ & & & & & & \\
\hline
\end{tabular}

Table 12 shows the descriptive statistics on the scores of the students in the DRI Test, while Table 13 shows the results of the one-way ANOVA on the scores based on socioeconomic levels.

Table 12. Descriptive statistics on the scores of the DMS scale based on socioeconomic levels

\begin{tabular}{lrrr}
\hline Socioeconomic Level & $N$ & $M$ & SD \\
\hline Higher & 173 & 7.13 & 1.35 \\
\hline Medium & 191 & 6.99 & 1.58 \\
\hline Lower & 179 & 5.93 & 1.67 \\
\hline
\end{tabular}

Table 13. ANOVA results on the scores of the DRI test based on socioeconomic levels

\begin{tabular}{lrrrrrr}
\hline $\begin{array}{l}\text { Source of } \\
\text { Variance }\end{array}$ & $\begin{array}{r}\text { Sum of } \\
\text { Squares }\end{array}$ & DF & $\begin{array}{r}\text { Mean } \\
\text { Squares }\end{array}$ & $F$ & $p$ & $\begin{array}{l}\text { Significant } \\
\text { Difference }\end{array}$ \\
\hline $\begin{array}{l}\text { Inter- } \\
\text { group }\end{array}$ & 152.761 & 2 & 76.381 & 32.091 & $.000^{*}$ & High-Low \\
\hline $\begin{array}{l}\text { Intra- } \\
\text { group }\end{array}$ & 1285.261 & 540 & 2.380 & & & Mid-Low \\
\hline Total & 1438.022 & 542 & & & & \\
\hline${ }^{*} p<.01$ & & & & & &
\end{tabular}

According to the results of the ANOVA, it was observed that the DRI test scores differentiated significantly based on socioeconomic levels $\left.\left(F_{(2-540}\right)=32.091\right)$. According to the results of the Dunnet $C$ test that was carried out to determine the groups between which this difference was obtained, it may be stated that there was a significant difference between the lower socioeconomic level and the other levels against the favor of the lower socioeconomic level.

In the data collection instrument, the students were additionally asked two Likert-type questions regarding the frequency of being asked their opinion in decisions made in the family and at school. With these questions, it was aimed to determine the perceptions of the student regarding the aforementioned situations. Whether or not there was a significant difference in the scores of the students in the DMS Scale and DRI test based on these perceptions was investigated. The descriptive statistics of the scores of the students in the DMS Scale are given in Table 14, while the results of the one-way ANOVA on the scores based on the frequency of the children being asked their opinion in decisions made at home are given in Table 15.

Table 14. Descriptive statistics of the scores in the DMS scale based on the frequency of the children being asked their opinion in decisions made at home

\begin{tabular}{lrrr}
\hline $\begin{array}{l}\text { My Family also Asks My Opinion in } \\
\text { Decisions Made at Home }\end{array}$ & $N$ & $M$ & SD \\
\hline Never-Rarely & 136 & 45.18 & 7.27 \\
\hline Usually & 127 & 46.75 & 6.10 \\
\hline Always & 280 & 52.31 & 6.71 \\
\hline
\end{tabular}

Table 15. ANOVA results on the scores in the DMS scale based on the frequency of the children being asked their opinion in decisions made at home

\begin{tabular}{lrrrrrr}
\hline $\begin{array}{l}\text { Source of } \\
\text { Variance }\end{array}$ & $\begin{array}{r}\text { Sum of } \\
\text { Squares }\end{array}$ & DF & $\begin{array}{r}\text { Mean } \\
\text { Squares }\end{array}$ & $F$ & $p$ & $\begin{array}{r}\text { Significant } \\
\text { Difference }\end{array}$ \\
\hline $\begin{array}{l}\text { Inter- } \\
\text { group }\end{array}$ & 5677.143 & 2 & 2838.572 & 62.840 & $.000^{*}$ & $\begin{array}{r}\text { Always } \\
\text { Usually }\end{array}$ \\
\hline $\begin{array}{l}\text { Intra- } \\
\text { group }\end{array}$ & 24392.409 & 540 & 45.171 & & & $\begin{array}{r}\text { Always } \\
\text { Rarely }\end{array}$ \\
\hline Total & 30069.553 & 542 & & & & \\
\hline${ }^{*}<.01$ & & & & & &
\end{tabular}

According to the results of the ANOVA, the scores of the students in the DMS Scale differed significantly based on the frequency of the children being asked their opinion in decisions made at home $\left(F_{(2-540)}=62.840\right)$. According to the results of the Scheffe test that was carried out to determine the groups between which this difference was obtained, it may be stated that there was a significant difference between the expression "Always" and other frequencies among the frequencies of the children being asked their opinion in decisions made at home in the favor of "always".

The descriptive statistics of the scores of the students in the DRI Test are given in Table 16, while the results of the one-way ANOVA on the scores based on the frequency of the children being asked their opinion in decisions made at home are given in Table 17.

Table 16. Descriptive statistics of the scores in the DRI test based on the frequency of the children being asked their opinion in decisions made at home

\begin{tabular}{lrrr}
\hline $\begin{array}{l}\text { My Family also Asks My Opinion in } \\
\text { Decisions Made at Home }\end{array}$ & $N$ & $M$ & SD \\
\hline Never-Rarely & 136 & 6.27 & 1.78 \\
\hline Usually & 127 & 6.93 & 1.56 \\
\hline Always & 280 & 6.79 & 1.55 \\
\hline
\end{tabular}

Table 17. ANOVA results on the scores in the DRI test based on the frequency of the children being asked their opinion in decisions made at home

\begin{tabular}{lrrrrrr}
\hline $\begin{array}{l}\text { Source of } \\
\text { Variance }\end{array}$ & $\begin{array}{r}\text { Sum of } \\
\text { Squares }\end{array}$ & DF & $\begin{array}{r}\text { Mean } \\
\text { Squares }\end{array}$ & $F$ & $p$ & $\begin{array}{r}\text { Significant } \\
\text { Difference }\end{array}$ \\
\hline $\begin{array}{l}\text { Inter- } \\
\text { group }\end{array}$ & 33.583 & 2 & 16.792 & 6.456 & $.000^{*}$ & $\begin{array}{r}\text { Always } \\
\text { (Never- } \\
\text { Rarely) }\end{array}$ \\
\hline $\begin{array}{l}\text { Intra- } \\
\text { group }\end{array}$ & 1404.439 & 540 & 2.601 & & & $\begin{array}{l}\text { Usually } \\
\text { (Never- } \\
\text { Rarely) }\end{array}$ \\
\hline Total & 1438.022 & 542 & & & & \\
\hline Tp<.01 & & & & & & \\
\hline
\end{tabular}

According to the results of the ANOVA, the scores of the students in the DRI Test differed significantly based on the frequency of the children being asked their opinion in decisions made at home $\left(F_{(2-540)}=6.456\right)$. According to the results of the Dunnet $C$ test that was carried out to determine the groups between which this difference was obtained, it may be stated that there was a significant difference between the expressions "Always" and "Never-Rarely" and between the expressions "Usually" and "Never-Rarely" in the favor of "Always" and "Usually".

The descriptive statistics of the scores of the students in the DMS Scale are given in Table 18, while the results of the oneway ANOVA on the scores based on the frequency of the children being asked their opinion in decisions made in the classroom are given in Table 19.

No significant difference was found in the scores of the DMS Scale based on the frequency of the children being asked their opinion in decisions made in the classroom. Accordingly, in 
DMS Scale scores, it may be stated that the factor of the frequency of the children being asked their opinion in decisions made in the classroom was not a significant variable.

Table 18. Descriptive statistics of the scores in the DMS scale based on the frequency of the children being asked their opinion in decisions made in the classroom

\begin{tabular}{lrrr}
\hline $\begin{array}{l}\text { My Teacher also Asks My Opinion in } \\
\text { Decisions Made in the Classroom }\end{array}$ & $N$ & $M$ & $S D$ \\
\hline Never-Rarely & 106 & 49.91 & 7.35 \\
\hline Usually & 134 & 49.33 & 7.43 \\
\hline Always & 303 & 48.95 & 7.45 \\
\hline
\end{tabular}

Table 19. ANOVA results on the scores in the DMS scale based on the frequency of the children being asked their opinion in decisions made in the classroom

\begin{tabular}{lrrrrrr}
\hline $\begin{array}{l}\text { Source of } \\
\text { Variance }\end{array}$ & $\begin{array}{r}\text { Sum of } \\
\text { Squares }\end{array}$ & DF & $\begin{array}{r}\text { Mean } \\
\text { Squares }\end{array}$ & $F$ & $p$ & $\begin{array}{l}\text { Significant } \\
\text { Difference }\end{array}$ \\
\hline $\begin{array}{l}\text { Inter- } \\
\text { group }\end{array}$ & 75.036 & 2 & 37.518 & .675 & .509 & \\
\hline $\begin{array}{l}\text { Intra- } \\
\text { group }\end{array}$ & 29994.517 & 540 & 55.545 & & \\
\hline Total & 30069.553 & 542 & & & \\
\hline$p<.01$ & & & & & & \\
\hline${ }^{*}$ & & & &
\end{tabular}

The descriptive statistics of the scores of the students in the DRI Test are given in Table 20, while the results of the oneway ANOVA on the scores based on the frequency of the children being asked their opinion in decisions made in the classroom are given in Table 21.

Table 20. Descriptive statistics of the scores in the DRI test based on the frequency of the children being asked their opinion in decisions made in the classroom

\begin{tabular}{lrrr}
\hline $\begin{array}{l}\text { My Teacher also Asks My Opinion in } \\
\text { Decisions Made in the Classroom }\end{array}$ & $N$ & $M$ & $S D$ \\
\hline Never-Rarely & 106 & 6.62 & 1.54 \\
\hline Usually & 134 & 6.67 & 1.61 \\
\hline Always & 303 & 6.72 & 1.67 \\
\hline
\end{tabular}

Table 21. ANOVA results on the scores in the DRI test based on the frequency of the children being asked their opinion in decisions made in the classroom

\begin{tabular}{lrrrrrr}
\hline $\begin{array}{l}\text { Source of } \\
\text { Variance }\end{array}$ & $\begin{array}{r}\text { Sum of } \\
\text { Squares }\end{array}$ & DF & $\begin{array}{r}\text { Mean } \\
\text { Squares }\end{array}$ & $F$ & $p$ & $\begin{array}{l}\text { Significant } \\
\text { Difference }\end{array}$ \\
\hline $\begin{array}{l}\text { Inter- } \\
\text { group }\end{array}$ & .851 & 2 & .426 & .160 & .852 & \\
\hline $\begin{array}{l}\text { Intra- } \\
\text { group }\end{array}$ & 1437.171 & 540 & 2.661 & & & \\
\hline Total & 1437.022 & 542 & & & & \\
${ }^{*} p<.01$ & & & & & &
\end{tabular}

No significant difference was found in the scores of the DRI Test based on the frequency of the children being asked their opinion in decisions made in the classroom. Accordingly, in DRI Test scores, it may be stated that the factor of the frequency of the children being asked their opinion in decisions made in the classroom was not a significant variable. Table 22 shows the descriptive statistics of the total scores of the students in the 1st-6th questions in the DRI Test.

Table 22. DRI test $1^{\text {st }} 6^{\text {th }}$ questions total score descriptive statistics

\begin{tabular}{lrrrrr}
\hline & $N$ & $M$ & Min. & Max. & $S D$ \\
\hline Questions 1-6. Total Scores & 568 & 5.07 & 0 & 6 & 1.46 \\
\hline
\end{tabular}

As seen in Table 22, the mean score of the students in their responses to the questions 1 to 6 was 5.07 . The first six questions on the test consisted of two questions regarding whether or not the students read the table right and four questions measuring the skills of the students to choose the option that is suitable for the given criterion. Considering the mean score in the table, it may be stated that the students were able to choose the suitable option.

Table 23 shows the descriptive statistics of the total score of the students in the 7th-9th questions in the DRI test.

Table 23. DRI test 7th-9th questions total score descriptive statistics

\begin{tabular}{|c|c|c|c|c|c|}
\hline & $\begin{array}{r}\text { Number } \\
\text { of Those } \\
\text { Who } \\
\text { Answered } \\
\text { Correctly }\end{array}$ & $\begin{array}{r}\text { Percentage } \\
\text { of Those } \\
\text { Who } \\
\text { Answered } \\
\text { Correctly }\end{array}$ & $\begin{array}{r}\text { Number } \\
\text { of Those } \\
\text { Who } \\
\text { Answered } \\
\text { Wrong }\end{array}$ & $\begin{array}{r}\text { Percent- } \\
\text { age of } \\
\text { Those Who } \\
\text { Answered } \\
\text { Wrong }\end{array}$ & $\mathrm{N}$ \\
\hline Question 7 & 231 & 40.7 & 337 & 59.3 & \\
\hline Question 8 & 362 & 63.7 & 206 & 36.3 & 568 \\
\hline Question 9 & 79 & 13.9 & 489 & 86.1 & \\
\hline
\end{tabular}

As seen in Table 23, the numbers of who answered correctly were $231(40.7 \%)$ for question 7, $362(63.7 \%)$ for question 8 and $79(13.9 \%)$ for question 9 . The $7^{\text {th }}$ question was as "If Ayşe wants the sound quality in a music player to be good, which music player should she choose?", and the students were expected to answer by thinking that the components of sound quality were CD player quality and radio quality. $40 \%$ of the students answered this question correctly. Accordingly, it may be stated that less than half of the students were successful in noticing the components forming criteria. The 8th question was as "I Ayşe wants the headphones of the music player to be comfortable and the quality to be high, which music player should she choose?", and the students were expected to respond by thinking of the scores of music players in the features given in the table together. $63.7 \%$ of the students answered this question correctly. Accordingly, most students could be considered to be successful in assessing situations involving multiple criteria. The 9th question was as "Considering the music players in the table, is there one that is clearly superior to the other? Explain your answer with your reasons." Although the music players on the table had different features, they were equal in terms of their total scores. In other words, there was no music player which was clearly superior to the other. In this question, the students were expected to see the big picture independently of their personal criteria and be able to assess situations with multiple criteria on a complex level. $13.9 \%$ of the students answered this question correctly. The students who answered this question correctly explained their response with statements as "Neither is clearly superior, because their total scores are the same" and "Has two good qualities and two bad ones, therefore equal." Those who gave wrong answers explained it with statements as " $\mathrm{A}$, because it has more qualities with 5 points" and " $A$, because its headphones and battery are better." Another group with wrong answers used the expressions of " $B$, because it does not have any quality with 1-2 points" and "B, because its scores are close to each other," showing that they had a tendency of considering the music player with average scores to be better.

The $10^{\text {th }}$ question of the DRI Test was as "Which music player would you choose if it were you? Explain with your reasons." In this question, the student was expected to make a decision based on own criteria and explain the reasons of this decision. Considering the answers of the students, it was seen that they could usually determine criteria unique to themselves and make their choices based on these criteria. Students in this group explained the reasons of their choices as "A, because I want a long battery life" and "B, because radio quality is important for me." Another group showed a tendency towards preferring the average in their choices 
and chose B. They explained this with the statements "I would choose $B$, because it does not have any qualities with 1-2 points", "B, because it is medium-level", " $B$, because its scores are uniformly distributed" and "B, because it does not have a score lower than 3." In addition to this, a group of students had a tendency to select the music player that they thought had a high total score, rather than selecting the music player that would satisfy their needs. They explained the reasons for this without basing their decision on a tangible criterion by saying "Because it is beautiful", "because it has quality" and "because it has 5 points.

The Choices and Outcomes Activity was developed to collect and investigate data on skills of being aware of - defining the decision situation and possible options, creating alternatives and predicting the possible outcomes of choices. In the light of the data obtained from the activity, it was seen that $44 \%$ of the students either answered incorrectly or left blank the question regarding expression - definition of the decision problem. Accordingly, it may be considered that close to half of the students experienced difficulty in defining - expressing a decision problem. In addition to this, $88 \%$ of the students correctly answered the question on creating alternative options towards the decision problem on a basic level. Accordingly, it may be stated that the vast majority of the students were able to create alternative options. $79 \%$ of the students correctly answered the question on predicting the possible outcomes of choices on a basic level. Accordingly, the vast majority of the students were successful in terms of being able to predict the possible outcomes of options.

\section{Discussion, Conclusion and Recommendations}

According to the teachers, the factors of family, teacher and social environment are important in the development of the decision-making skills of students. In the framework drawn regarding the factor effective on development of decision-making in the study by Mettas and Norman (2011), curricula are at the center. It was reported that the style of the teacher in implementation of the curriculum, their perspective towards learning and teaching and instruction materials and resources are effective variables in the process of developing decision-making skills in children. Additionally, another dimension effective on decision-making and in the development of decision-making skills was determined to include the age of the child, peer effects, skills of transferring learning, strategy used in decision making, motivation, information sources that are used and assessment criteria. Moreover, it was stated that another dimension effective on decision-making and the development of decision-making skills include knowledge, skills and values regarding the nature of decision-making or the issue of making a decision. In their views on the factors effective on development of decision-making, the teachers did not mention many of the aforementioned dimensions including the curricular dimension. The views of the teachers were limited to providing the child with a democratic environment and creating decision-making experiences. The reasons for this situation are believed to be the deficiency of the awareness of the teachers on decision-making, lack of knowledge, ambiguity of decision-making skills in curricula and failure to guide teachers in this matter. Consequently, the criticisms of the classroom teachers who participated in the study regarding development of decision-making skills were towards the curricula and themselves.

The teachers stated that students experienced difficulties in the steps of understanding the decision situation, examining options and deciding upon an option, while they considered criteria unrelated to the decision situation. The finding from the decision-making activity that was applied that $44 \%$ of the students experienced difficulty in defining - expressing the decision problem was in agreement with the statements of the teachers. Howse et al. (2003) reported that small children experience problems in distinguishing the relevant and irrelevant information to be used in decision-making situations from each other, as well as eliminating options. Davidson (1991) emphasized that the skills of a child to assess information related to options develop by age, a child who can easily eliminate options with irrelevant information gets the opportunity to gain more information on the fewer options that remain, and this way, they can make better decisions. This situation might have been effective in the students' difficulties while decision-making.

The teachers thought that students wanted their decisions to be made for them, they avoided decision-making and experienced indecisiveness. The teachers stated that this result was caused by lack of decision-making experiences of students, failure to include them in decision-making processes, not including them in democratic settings and them growing up in protective family environments. Yalçınkaya-Dulkadiroğlu (2001) emphasized that protective family attitudes lead to development of a dependent personality in the child, and participation in family decisions will contribute to the child making more rational decisions at further ages.

The teachers reported that they provided their students with a democratic setting as they thought that a democratic environment where students can express their opinions is important in the development of their decision-making skills. The contribution of environment where thoughts can be freely expressed, and decision-making opportunities are created on development of the child's decision-making skills is clear. The study by Brown and Mann (1990) showed that the children of families with good communication and conflict resolution skills make more careful decisions. Nevertheless, in order to understand the extent to which teachers can offer such environments for their students, there is a need for long-term in-class observations.

The teachers stated that they mostly utilized interdisciplinary practices in development of students' decision-making skills, rather than activities directly related to decision-making steps. One may state that interdisciplinary practices are included in the curricula in terms of development of decision-making skills. However, activity-based practices where decision-making steps are taken on directly should also be employed. Nardi and Wales (1985) highlighted that decision-making is a skill that surpasses the limits of a course or discipline, and it should be provided at all stages of education in an integrated, direct and clear manner.

The teachers believed that decision-making skills were not clear in the curricula, relevant targeted outcome and activity dimensions were lacking, they did not have awareness of the position of this skill in the curricula, and they needed information and guidance regarding decision-making. Considering the curricula of primary school, it was seen that decision-making skills were mostly among the targeted outcomes of the $1^{\text {st }}, 2^{\text {nd }}$ and $3^{\text {rd }}$ grade Social Studies curricula. No related targeted outcome was encountered in the 4th grade Social Studies curriculum, and it was stated that decision-making is included in skills that are to be directly provided. The $4^{\text {th }}$ grade Science and Technology curriculum included one targeted learning outcome related to decision-making, but it is debatable whether or not this outcome could be included in the scope of decision-making ([the student] decides whether a being is living or inanimate by inquiry). In the curriculum of the Turkish course, decision-making skills were associated with the intermediary discipline of Human Rights and Citizenship ([the student] participated in the decision-making processes at school) under the learning area of "Reading". In addition to this, although several activities were included in the Turkish curriculum related to development of this skill, no targeted learning outcome was written. The Mathematics curriculum did not include any targeted outcome, activity or association with an intermediary 
discipline. Pekdoğan (2016) argued that thinking and learning skills need to be integrated into different forms in development of decision-making skills and recommended usage of activities including rich learning experiences where different disciplines are combined. Based on the teachers' views and the research on the curricula, it may be stated that the curricula had a set of shortcomings in terms of development of decision-making skills in the dimensions of outcomes, contents and guidance of teachers.

According to the quantitative results of the study, the scores obtained from the DMS Scale were significantly different in favor of the female students, while the scores obtained from the DRI Test did not differ significantly based on sex. In the literature, there are studies which reported sex to be a significant variable in terms of decision-making (Brown \& Mann, 1990; Sanz de Acedo Lizárraga, Sanz de Acedo Baquedano, \& Cardelle-Elawar, 2007; Van Leijenhorst, Westenberg, \& Crone, 2008), while there are also those that found it to be insignificant (Chung, 2002; Geisler \& Allwood, 2015; Moschis \& Moore 1979; Sonfield, Lussier, Corman \& McKinney, 2001; Zhang, Pelowski, Jia \& Yu, 2017). In the emergence of this situation, influential factors may include that, decision making, in a very broad perspective (strategic decision-making, logical decision-making, administrative decision-making, decision-making career selection, social decision-making, decision-making in risky situations, etc.), has a multidimensional structure (information gathering, risk perception, containment effect, ambiguity situations, implementation of decision rules, etc.), and studies have so far included the aforementioned, different contexts. However, studies in the literature that showed sex as an insignificant variable were in the majority. While the DMS Scale reveals the perceptions of students regarding themselves, the DRI Test measures the success of students in implementing decision rules independently of perceptions. Considering this issue, it may be stated that the results were in agreement with those in the literature.

The results of the study showed that the scores obtained from the DMS Scale and DRI Test did not differ significantly based on the factor of age. In general, studies in the literature stated that the factor of age is a significant variable in terms of decision-making (Crone \& Van Der Molen, 2007; Levin, Hart, Weller, \& Harshman, 2007), and it is in fact a developmental process (Byrnes, 1998). These studies investigated the differences among children, youths and adult groups. The participants of this study consisted of children with similar developmental characteristics who were enrolled on the same grade level and at the ages of 9-11. It is believed that this situation was effective on the finding that the age factor did not lead to a significant difference in the results of the study.

The scores obtained from the DMS Scale and DRI Test differed significantly based on the numbers of children in the families. For both measurement instruments, this difference was between the children with no siblings or one sibling and those with more than one sibling and in favor of those without siblings or one sibling. It is believed that the number of children in the family is negatively related to the time allocated per child, inclusion of the child in decision-making processes and paying importance to the views of the child. According to the results of the one-way ANOVA that was carried out based on the frequency of children being asked their opinion in decisions made at home from this perspective, there were significant differences between the children who were single children or had only one sibling $(M=3.32)$ and those with more than one sibling $(M=2.83)$ $\left(t_{(535)}=23.655, p<.001\right)$ in terms of their frequencies of being asked their opinion in decisions made at home. In parallel to this, it is also stated that the size of the family is a variable that is influential on the cognitive development of the child
(Blake, 1981; Zajonc, 1976; Zajonc \& Marcus, 1975). The significantly higher scores of the children with no siblings or one sibling in the DMS Scale and DRI Test in comparison to the other children may be explained by this.

The scores obtained from the DMS Scale differed significantly based on socioeconomic levels. This difference was between the medium and higher and between the medium and lower socioeconomic levels, in favor of the medium level. While there was a positive relationship among the socioeconomic levels in the study, it was observed that the mean scores of the higher and lower socioeconomic levels were very close to each other. It is believed that this situation emerged as a consequence of the structure of the DMS Scale that reveals the perceptions of students regarding themselves. According to the findings, it may be stated that the students on the lower and higher socioeconomic levels had similar perceptions.

The scores obtained from the DRI Test differed significantly based on socioeconomic levels. This difference was between the lower socioeconomic level and the other socioeconomic levels against the favor of the lower socioeconomic level. In the one-way ANOVA between the frequency of the children being asked their opinion in decisions made at home and their socioeconomic levels, a significant difference was found was between the lower socioeconomic level and the other socioeconomic levels against the favor of the lower socioeconomic level $\left(F_{(2.540)}=29.655, p<.001\right)$. In other words, the children from a lower socioeconomic background thought that their opinions were asked in the family less frequently in comparison to the other children. Considering these two findings together, it may be stated that the children on a lower socioeconomic level thought they were asked their opinion less frequently in their families and received lower scores in the DRI test. Brown and Mann (1990) reported that individuals on a higher socioeconomic level were more careful in terms of decision-making in comparison to those on a lower socioeconomic level. In this sense, it may be argued that the finding of the study was in agreement with the literature.

The scores obtained from the DMS Scale DRI Test differed significantly based on the frequency of the children being asked their opinion in decisions made at home. Based on this finding, it may be stated that the children who thought their opinions were asked more frequently at home also received higher scores in the scale and the success test. Doğanay (2011) reported that children learn thinking not by observing or memorizing others' thought but by interacting with their environment and other materials. Byrnes (2005) stated that children who are allowed to make their own decision and experience the outcomes of decisions (in a safe environment) will sooner or later internalize strategic approaches related to decision-making and develop decision-making skills. The high decision-making scores of the children whose opinions are cared for at home may be considered to be related to the thinking-friendly environments and decision-making opportunities offered to the child.

The scores obtained from the DMS Scale DRI Test did not differ significantly based on the frequency of the children being asked their opinion in decisions made in the classroom. In the ANOVA conducted to interpret this finding, no significant difference was found among the schools on different socioeconomic levels in terms of inclusion of the opinions of the children. This finding may be interpreted as that the teachers in the sample prioritized the opinions of the students on the same level regardless of the differences in their socioeconomic levels. This may explain the finding that, while inclusion of the opinions of the child at home influenced their decision-making score, inclusion of the opinions of the child at school did not affect it. 
In the DRI Test, the students were presented with decision-making task that asked them to consider certain criteria and they were asked to choose the option that complied with these criteria. According to the results of the DRI Test, it may be stated that the students were successful in choosing the suitable option by eliminating the options that were not suitable for the determined criteria. It was also observed in the test that the students were able to make choices suitable for the criteria they determined themselves. Studies have shown that children who are given decision-related tasks are able to eliminate the alternatives that they find unacceptable on a certain level (Davidson, 1991; Klayman, 1985). Accordingly, it may be stated that the findings of the study agreed with those in the literature.

According to the results of the DRI Test, $63.7 \%$ of the students were successful in assessing situations involving multiple criteria on a basic level. The study by Klayman (1985) demonstrated that 12-year-old children could develop strategic approaches in assessment of options with multiple criteria. However, when the situation including multiple criteria was elevated to a complex level, the success rate dropped to $13.9 \%$. The students were given an example of a case in the Choic es and Outcomes activity, and they were asked open-ended questions related to this. Accordingly, $44 \%$ of the students experienced problems in defining - expressing the decision problem. The PISA 2012 National Report stated that the reading skill scores of Turkey were under the average value among the OECD countries (MEB, 2015). It is believed that the emergence of this result was associated with the skills of the students in understanding what they read and expressing it.

According to the results obtained from the Choices and Outcomes Activity, the students were able to create alternatives on a basic level and foresee the possible outcomes of their choices. Crone and van Der Molen (2007) stated that children experience problems in terms of predicting the possible outcomes of their choices, while this skill continues to show development from childhood towards the end of adolescence. It is considered that this difference among the studies emerged as a result of the differences in the complexity levels of the decision situations utilized in the measurement instruments. In this study, the teachers stated that they utilized interdisciplinary practices in development of decision-making skills. Nevertheless, it may be useful to include specific decision-making activities or practices involving decision-making steps while teaching decision-making. The teachers reported that their awareness of the place of decision-making skills in the curricula was low, they needed guidance and information on the issue, and there were shortcomings in the curricula on the dimensions of targeted learning outcomes and activities. Considering the curricula, it may be argued that the teachers were right regarding the aforementioned issues. The curricula may be improved in terms of the issues of targeted outcomes, activities and guidance of teachers.

In the curricula, decision-making skills are aimed to be provided with an interdisciplinary approach, and in parallel to this, they are included among the common skills that need to be gained. Considering the existing situation in the curricula, it may be stated that these skills are not sufficiently included. In this context, employing practice-based activities where decision processes are taken on in a detailed way may contribute to development of decision-making skills. The teachers stated that they had family-related problems in developing decision-making skills. In addition to this, in the light of the information obtained from the measurement instruments, it was observed that asking the opinion of the child in decisions made at home created significant differences in the child's decision-making skills. In this context, one may argue that family trainings will provide suitable environments for decision-making skills to develop. In this study, the decision-making skills of the children were aimed to be measured by a Likert-type measurement instrument, a success test and an open-ended form with an example of a case developed by the researcher. In studies to be carried out, more in-depth data could be obtained by including clinical observations based on real cases where the decision-making processes of the child are examined.

\section{Acknowledgments}

We would like to thank Anadolu University Projects Unit for providing financial support for the conduct of the research (Project No:1506E489).

\section{References}

Akdaş, H., B. (2013). Sosyal bilgiler dersinde güncel olaylardan yararlanmanın öğrencilerin karar verme becerilerine etkisi [The effect of teaching activities prepared in accordance with current events in social studies lesson on student's decision making skills]. Unpublished master's thesis. Gazi University, Ankara, Turkey.

Blake, J. (1981). Family size and the quality of children. Demography, 18(4), 421-442.

Boyatzis, R. E. (1998). Transforming qualitative information: Thematic analysis and code development. USA: Sage Publications.

Brannen, J. (2005) Mixed methods research: a discussion paper. Retrieved October 23, 2014, from http://eprints. ncrm.ac.uk/89/1/MethodsReviewPaperNCRM-005.pdf

Bronstein, L. (1992). The effect of a school-based parent training program on parents' and childrens' social problem-solving and decision-making skills. Unpublished PhD Thesis. New Jersey : Rutgers The State University.

Brown, J. E. \& Mann, L. (1990). The relationship between family structure and process variables and adolescent decision making. Journal of Adolescence, 13(1), 25-37.

Byrnes, J. P. (1998). The nature and decelopment of decision-making: A self regulation model. USA: Earlbaum Manwah NJ.

Byrnes, J. P. (2005). The development of judgement and decision making in children and adolescents. In J.E. Jacobs \&. P.A. Klaczynski (Eds.), In The development of self-regulated decision making (pp. 5-38). Lawrence Erlbaum.

Cenkseven Önder, F. (2012). The influence of decision-making styles on early adolescents' life satisfaction. Social Behavior and Personality, 40(9), 1523-1536.

Chung, Y. B. (2002). Career decision-making self-efficacy and career commitment: Gender and ethnic differences among college students. Journal of Career Development, 28(4), 277-284.

Creswell J.W. \& Plano Clark, V.L. (2014). Karma yöntem araștırmaları tasarımı ve yürütülmesi [Designing and conducting of mixed method research] (Y. Dede, S.B. Demir, Trans.). Ankara: Anı Yayıncılık.

Crone, E. A. \& Van Der Molen, M. W. (2007). Development of decision making in school-aged children and adolescents: Evidence from heart rate and skin conductance analysis. Child Development, 78(4), 1288-1301.

Çakmakçı, E. (2009). Karar verme becerilerinin kazandırılmasında drama dersinin ilköğretim 4. sını öğrencileri üzerindeki etkilerinin incelenmesi [Examination of the effect of drama lessons on 4th grade students of primary school when bringing in the abilities of decision making]. Unpublished master's thesis Osmangazi Üniversitesi, Eskişehir, Turkey. 
Çolakkadıŏglu, O. (2010). Çatıs̆ma kuramına dayalı olarak geliştirilen karar verme beceri eğitimi grup uygulamalarının ergenlerin karar verme stillerine etkisi [The effect of conflict theory based decision making skill training group applications on decision making styles of adolescents]. Unpublished doctoral thesis. Çukurova University, Adana, Turkey.

Davidson, D. (1991). Children's decision-making examined with an information-board procedure. Cognitive Development. 6, 77-90.

Doğanay, A. (2011). Etkin vatandaşlık için düşünme becerilerinin öğretimi [Teaching thinking skills for effective citizenship]. In C. Öztürk (Ed.), Sosyal bilgiler öğretimi demokratik vatandașlık eğitimi [Social studies education democratic citizenship education] (s. 146-185). Ankara: Pegem Akademi.

Doğanay, A., \& Sarı, M. (2012). Düşünme dostu sınıf ölçeği (DDSÖ) geliştirme çalışması [Thinking-friendly classroom scale development study]. Ilköğretim Online, $11(1), 214-229$

Eccles, J. S., Lord, S. \& Buchanan, C. M. (1996). School transitions in early adolescence: What are we doing to our young people? In J.L. Graber, J. Brooks-Gunn and A.C. Petersen (Eds.), Transitions through adolescence: Interpersonal domains and context. (251-284). Mahwah, N.J: Lawrence Erlbaum.

Geisler, M. \& Allwood, C. M. (2015). Competence and quality in real-life decision making. PloS One, 10(11). doi: 10.1371/journal.pone.0142178.

Gelman, R. (1969). Conservation acquisition: a problem of learning to attend to relevant attributes. Journal of Experimental Child Psychology, 7, 167-187.

Goloğlu, S. (2009). Fen eğitiminde sosyo-bilimsel aktivitelerle karar verme becerilerinin geliştirilmesi: dengeli beslenme [Developing decision making skills with socio-scientific activities in science eduaction: Balanced (healthy) nutrition]. Unpublished master's thesis. Marmara University, Istanbul, Turkey.

Gömleksiz, M. N., ve Kan, A. Ü. (2007). İlköğretim 5. sınıf Türkçe dersi öğretim programının problem çözme ve karar verme becerilerini kazandırmadaki etkililik düzeyine ilişkin öğrenci görüşlerinin değerlendirilmesi [An assessment of students' perceptions of efficiency level of gaining problem-solving and decision making skills of fifth grade turkish language education curriculum]. Gazi Eğitim Fakültesi Dergisi, 27(3), 51-63.

Hagen, W. J. and Hale, A. G. (1973). The development of attention in children. ETS Research Bulletin Series. 1973(1), 1-37.

Hansson, S.O. (2005). Decision theory: A brief Introduction. Stockholm: Royal Institute of Technology.

Howse, B. R., Best, L. D. \& Stone, R. E. (2003). Children's decision making: the effects of training, reinforcement and memory aids. Cognitive Development. 18, 247268.

Johnson, A. P. (2010). Building a framework for social studies. In A. P. Johnson (Ed.), Making connections in elementary and middle school: Social studies (pp. 1-24). Thousand Oaks, CA: Sage Publications.
Karakaş Günal, E. (1999). Illköğretim 4. ve 5. sınıf öğrencilerinin günlük yaşamlarındaki problemlerini çözmeye iliş̧in karar verme becerilerini ölçmeye yönelik bir ölçek geliştirme çalışması [Development of a scale to measure decision making skills recated to every day problems of fourth and fifth grade students]. Unpublished master's thesis. Çukurova University, Adana, Turkey.

Kardaş, N. (2013). Fen eğitiminde argümantasyon odaklı öğretimin ögrencilerin karar verme ve problem çözme becerilerine etkisi [The impact of argumentation focused teaching in science education on the decision making and problem solving skills of students]. Unpublished master's thesis. Osmangazi University, Eskişehir, Turkey.

Kaşkaya, A., Calp, Ş., Kuru, O. (2017). An evaluation of factors affecting decision making among 4th grade elementary school students with low socio-economic status. International Electronic Journal of Elementary Education. 9(4), 787-808. Retrieved from https://www.iejee. com/index.php/IEJEE/article/view/285

Klaczynski, A. P., Byrnes, P. J. and Jacobs, E. J. (2001). Introduction to the special issue the development of decision making. Applied Development Psychology, 22, 225-236.

Klayman, J. (1985). Children's decision strategies and their adaptation to task characteristics. Organizational Behavior and Human Decision Processes, 35, 179-201.

Korkut, F. (2004). Okul temelli önleyici rehberlik ve psikolojik danışma [School-based preventive guidance and counseling]. Ankara: Anı Yayıncılık.

Köseoğlu, E. (2014). Ilkokul 4. sınıflarda drama etkinlikleriyle işlenen derslerin öğrencilerin problem çözme ve karar verme becerileri üzerindeki etkilerinin incelenmesi [Investigating the effects of students troubleshooting and decision making skills by teaching with drama activities at primary school fourth grades]. Unpublished master's thesis. Atatürk University, Erzurum, Turkey.

Levin, I. P., Hart, S. S., Weller, J. A. \& Harshman, L. A. (2007). Stability of choices in a risky decision-making task: a 3-year longitudinal study with children and adults. Journal of Behavioral Decision Making, 20(3), 241-252.

Marzano, R. J., Brandt, R. S., Hughes, C. S., Jones, B. F., Presseisen, B. S., Rankin, S.C., \& Suhor, C. (1988). Dimension of thinking: A framework for curriculum and instruction. Virginia: ASCD.

MEB. (2008). Sosyal bilgiler dersi (4-5. sınıflar) öğretim programı ve kılavuzu [Social studies (4th.-5th. Classes) curriculum and instruction manual]. Retrieved October 20, 2014, from http://ttkb.meb.gov.tr/program2. aspx?islem $=2 \& \mathrm{kno}=38$

Mettas, A., \& Norman, E. (2011). A grounded theory approach to the development of a framework for researching children's decision-making skills within design and technology education. Design and Technology Education: An International Journal, 16(2), 8-19.

Moschis, G. P. and Moore, R. L. (1979). Decision making among the young: a socialization perspective. Journal of Consumer Research, 6(2), 101-112. 
Nardi, H. A. \& Wales, E. C. (1985). Teaching decision making with guided design. In A.L. Costa (Ed.), Developing minds: A resource book for teaching thinking (pp. 222225). Alexandria VA: ASCD.

NCSS (1998). A report from NCSS task force on early childhood/elementary social studies. Retrieved November 20, 2014, from http://www.socialstudies.org/positions/elementary

Nicolaou, T. C., Korfiatis, K., Evagorou, M. and Constantinou, C. (2009). Development of decision-making skills and environmental concern through computer-based, scaffolded learning activities. Environmental Education Research. 15(1), 39-54.

Öncül, B. (2013). Ilköğretim 4. Sınıf öğrencilerinin karar verme becerilerine ilişkin sınıf öğretmenlerinin görüşleri [Teachers opinions about the primary 4th graders decision making skills]. Unpublished master's thesis. Anadolu University, Eskişehir, Turkey.

Pekdoğan, S. (2016). Çocuklarda karar verme becerileri ve etkinlik örnekleri [Decision making skills in children and activity examples]. Ankara: Eğiten Kitap.

Sanz de Acedo Lizárraga, M. L., Sanz de Acedo Baquedano, M. T. \& Cardelle-Elawar, M. (2007). Factors that affect decision making: gender and age differences. International Journal of Psychology and Psychological Therapy, 7(3), 381-391.

Sever, I., Ersoy, A. (2019). İlkokul öğrencileri için karar verme becerisi ölçeğinin geliştirilmesi: Geçerlik ve güvenirlik çalışması [Development of decision making skills scale for primary school students: Validity and reliability study]. Cukurova University Faculty of Education Journal, 48(1), 662-692. Retrieved from https://dergipark.org. tr/tr/pub/cuefd/issue/44511/533443

Sonfield, M., Lussier, R., Corman, J. \& McKinney, M. (2001). Gender comparisons in strategic decision-making: an empirical analysis of the entrepreneurial strategy matrix. Journal of Small Business Management, 39(2), 165 173.

Tashakkori, A. \& Teddlie, C. (2010). Sage handbook of mixed methods in social and behavioral research. SAGE. Retrieved October 23, 2014, from http://www.sagepub. com/upm-data/34743_Chapter1.pdf

Tekin, S., ve Ulaș, A. (2016). illkokul 4. sınıf öğrencilerinin karar verme becerilerine ilişkin bir araştırma [A research on the decision making skills of 4th grade students]. Qualitative Studies, 11(3), 27-38.

Tetik, A. T. (2013). Sosyal bilgiler dersinde kullanılan probleme dayalı ögrenme yönteminin ögrencilerin karar verme becerisine etkisi [The effect of problem-based learning method on the decision-making skills of students at the social studies lesson]. Unpublished master's thesis. Mehmet Akif Ersoy University, Burdur, Turkey.

Van Leijenhorst, L., Westenberg, P. M. \& Crone, E. A. (2008). A developmental study of risky decisions on the cake gambling task: age and gender analyses of probability estimation and reward evaluation. Developmental Neuropsychology, 33(2), 179-196.

Weller, J. A., Levin, I. P., Rose, J. P. \& Bossard, E. (2012). Assessment of Decision-making Competence in Preadolescence. Journal of Behavioral Decision Making, 25(4), 414-426.
Weller, J. A., Moholy, M., Bossard, E. \& Levin, I. P. (2014). Preadolescent decision-making competence predicts interpersonal strengths and difficulties: A 2-year prospective study. Journal of Behavioral Decision Making, 28(1), 76-88.

Yalçınkaya-Dulkadiroğlu, H. (2001). ilköğretim okulu 11-16 yaş öğrencilerinin ailede karar vermeye katılımı konusundaki görüşleri [Views of the children, who are primary school's students in 11-16 age group, about decision making in family]. Unpublished master's thesis. Gazi University, Ankara, Turkey.

Zajonc, R. B. \& Markus, G. B. (1975). Birth order and intellectual development. Psychological Review, 82(1), 74.

Zajonc, R. B. (1976). Family configuration and intelligence. Science, 192(4236), 227-236.

Zhang, M., Liu, T., Pelowski, M., Jia, H. \& Yu, D. (2017). Social risky decision-making reveals gender differences in the TPJ: a hyperscanning study using functional near-infrared spectroscopy. Brain and Cognition, 119, 54-63. 